\title{
NUCLEIC ACID CONTENT IN DIFFERENT TISSUES OF FRESHWATER CRAB BARYTELPHUSA GUERINI IN RELATION TO REPRODUCTION
}

\author{
Ghorpade B.R. \\ Dept. of Zoology, Shri Anand College, Pathardi Dist. Ahmednagar (M.S.) 414102 \\ *Corresponding Author: bhaughorpade2007@gmail.com
}

\begin{abstract}
The present study was undertaken to access the reproductive cycle, and nucleic acid content of the freshwater crab, Barytelphusa guerini, during different reproductive seasons of the year. The freshwater crabs are available abundantly in lakes and ponds of study area. They were collected from Shirsatwadi and Kuttarwadi dam near Pathardi. The nucleic acid content in gonads and hepatopancreas in relation to reproduction was studied during different reproductive seasons. Study showed that during maturation, nucleic acid content increased in the gonads and decreased in hepatopancreas. During preparatory phase nucleic acid were higher in gonad and hepatopancreas. The reproductive cycle and nucleic acid content in gonads and hepatopancreas was studied during different months of the year.
\end{abstract}

Key words: - Barytelphusa guerini, reproductive stage, DNA content, RNA content..

\section{INTRODUCTION:}

The decapod crustaceans are commercially important as they are with high nutritional contents. Crabs are commercially important and command high price as there is a rapidly expanding demand for crab meat both in local and international markets. Crab has a unique and delicious taste as compared with fish and mollusc. Barytelphusa guerini is most popular because of its size, meat quality and it is consumed largely as a protein source. A nucleic acid is a macromolecule composed of chains of monomeric nucleotides. These molecules carry genetic information or form structures within cells. Nucleic acid is nitrogen containing compounds of high molecular complexes and is known to be in association with proteins in the cell.

Reproduction is the main mechanism that keeps species continuity so that it contributes to regulate the population size. Biochemical composition of the gonads and whole body in relation to reproductive cycle has been studied in some species of prawns and crabs. Weiqun Lu et al., (2001) studied characterization of cDNA encoding molt inhibiting hormone of the crab, Cancer pagurus. Rosa and Nunes (2004) described the seasonal variations in DNA-RNA concentrations in the muscles of juvenile Aristeus antennatus and its relation to reproduction, growth and nutritional conditions. Rosa and Nunes (2004) described the seasonal variations in nucleic acid contents and amino acid profiles in juvenile Nephros norvegicus. The hepatopancreas and ovary are considered to be the synthetic sites of vitellogenin in the giant tiger prawn Penaeus monodon, as based on gene expression studies (Avarre et al., 2003). Raviv et al., (2006) studied and sequenced the L. vannamei Vg c DNA in penaeid shrimp. Shirley et al., (2008) reported cloning and characterization of cDNA from hepatopancreas to ovary. 
The studies on crustaceans indicated that the hepatopancreas and ovary are responsible for $\mathrm{Vg}$ synthesis based on the existence of $\mathrm{Vg}$ mRNA, and it is hypothesized that Vg gene expression in these tissues is regulated in a tissue-specific manner. A positive correlation between RNA concentration and growth rate has been demonstrated in many organisms of widely different taxa. The studies reported high RNA levels in the hepatopancreas during the early and late exogenous vitellogenic stages, but the highest RNA levels during the early exogenous vitellogenic stage occurred in the ovary. The Vg from the hepatopancreas is released into the haemolymph and remain in this from, but the $\mathrm{Vg}$ in ovary undergoes second cleavage, which probably occur as with certain delay during ovarian maturation. The present investigation has been undertaken to account for the monthly content changes occurred in the DNA and RNA in gonads and the hepatopancreas of the freshwater crab, Barytelphusa guerini in relation to reproduction.

\section{MATERIALS AND METHODS:}

The freshwater crabs Barytelphusa guerini were collected from Shirsatwadi and Kuttarwadi dam, near Pathardi, DistAhmednagar (M.S.) for the period January to December 2014. The crabs were kept separately in aerated water in glass aquarium. They were acclimatized to laboratory conditions for three days before carrying out the experiment.

DNA extraction: Total genomic DNA was extracted by geneOmbio DNA extraction kit protocol. $150 \mathrm{mg}$ of each tissue sample was processed for DNA extraction. Lysis of tissue by Proteinase $\mathrm{K}$ digestion at warm temperature, purification of DNA by phenol chloroform extraction and finally precipitation of DNA by isopropanol are the major steps involved in DNA extraction protocol (Sambrook et al., 1989). Dried DNA was dissolved in $40 \mu 1$ of DNA storage buffer for further studies.

DNA estimation: The content of DNA in gonads and hepatopancreas was estimated by using UV spectrophotometry. DNA absorbs UV light very efficiently, making it possible the quantity of DNA was determined. The nitrogenous bases in nucleotides have an absorption maximum at about $260 \mathrm{~nm}$. Using the OD $260 \mathrm{~nm}$ for each sample, quantity of DNA in testis and ovary at different seasons was determined (Rosa and Nunes 2004).

RNA estimation:

The content of RNA in testis and ovary was checked by using UV spectrophotometry. RNA absorbs UV light very efficiently, making it possible the quantity of RNA was determined. The nitrogenous bases in nucleotides have an absorption maximum at about $260 \mathrm{~nm}$. Using the OD $260 \mathrm{~nm}$ for each sample, quantity of RNA in testis and ovary at different seasons was determined (Rosa and Nunes 2004). RESULTS AND DISCUSSION:

Total DNA content in different tissues of crab Barytelphusa guerini shows variations from season to season. The highest DNA content in Barytelphusa guerini ovary was found in the month of September and lowest was found in January. In testis, higher DNA content was found in the month of July, whereas in hepatopancreas highest and lowest DNA content was found in month September and January respectively. The seasonal analysis of DNA content in different body tissues of Barytelphusa guerini and results are given in table 1 and illustrated in fig-I .

\section{RNA}

Total RNA content in different tissues of crab Barytelphusa guerini shows variations from season to season. The highest RNA content in 
Barytelphusa guerini ovary was found in the month of June and lowest was found in January. In testis, higher RNA content was found in the month of July, whereas in hepatopancreas highest and lowest RNA content was found in month October and January respectively. The seasonal analysis of RNA content in different body tissues of Barytelphusa guerini and results are illustrated in Fig. II

Hepatopancreas of crustacean was earlier considered only as a digestive gland is now confirmed to play an important role in physiological process. In the crabs, a decrease in Vitellogenin synthesis by the hepatopancreas, in the absence of $\mathrm{VIH}$, suggests additional regulators of $\mathrm{Vg}$ synthesis. The present study was carried out to know the role of hepatopancreas during nonbreeding and breeding season of crab Barytelphusa guerini. It is observed that the nucleic acid content of hepatopancreas is at its highest during the breeding season. Circulating levels of $\mathrm{Vg}$ in the hemolymph of Dungeness crabs displayed a pattern similar to other crustacean species (Byard and Aiken 1984; Tsukimura et al. 2000) where maximum Vg concentration is observed well before egg extrusion. This may coincide with the time when maximum accumulation of extra-oocyte $\mathrm{Vg}$ begins or may be due to a direct decrease in Vg synthesis by the hepatopancreas. Pooyan (1998) suggested that both hepatopancreas and ovary are responsible for synthesizing Vg. Shaul Raviv et al., (2006), showed that Vg gene expression is significantly higher in the ovary than in the hepatopancreas in induced sub-adult females and the pattern of $\mathrm{Vg}$ expression has an inverse relationship with the molt event. The mRNA represents the site of expression of the yolk precursor gene, and it is the most reliable criterion for defining the site of vitellogenin synthesis. In crustaceans, the vg is synthesized in multiple organs, depending on species and vitellogenesis (Abdu et al., 2002; Tsutsui et al., 2004; Avarre et al., 2003; Tsang et al., 2003). Tsutsui et al., (2000) found Vg mRNA synthesized simultaneously in hepatopancreas and ovarian tissues of vitellogenic Penaeus japonicus females related to ovarian maturation. They found high mRNA levels in the hepatopancreas during the early and late exogenous vitellogenic stages, but the highest mRNA levels during the early exogenous vitellogenic stage occurred in the ovary and thereafter, levels rapidly declined. Kulkarni and Balkhande (2016) reported decrease in RNA and DNA in Hapatopancreas of crab was due to stress condition of urea whereas RNA and DNA were found increase in additive treated crab. Avarre et al., (2003) showed that hepatopancreas and ovarian tissues are involved in the expression of $\mathrm{Vg}$ mRNA in $P$. semisulcatus. The $\mathrm{Vg}$ from the hepatopancreas is released into the haemolymph and remains in this form, but the $\mathrm{Vg}$ in ovary undergoes second cleavage, which probably occurs with a certain delay during ovarian maturation.

\section{CONCLUSION:}

In the present study DNA and RNA content of testis, ovary and hepatopancreas of Barytelphusa cunicularis at different seasons were detected. The DNA/RNA content varied from season to season. During reproductive season the gonadal nucleic acid content was high as compared to non breeding season. Nucleic acid content in different tissues in the freshwater fish N.notopterus in relation to sex was studied during Pre-spawning phase of the reproductive cycle by Ravikiran and Kulkarni (2015).

The RNA content was low during previtellogenic stage and dramatically increased during vitellogenic stage and 
decreased significantly in post vitellogenic stage. During the post vitellogenic stage, the RNA content was decreased in hepatopancreas, while they decreased significantly in ovary. In the present study the significant increase in DNA and RNA contents from winter to summer may be related to protein synthesis.

\section{ACKNOWLEDGEMENT}

\section{REFERENCES:}

Abdu U, Davis C, Khalaila I, Sagi A, 2002. The vitellogenin cDNA of Cherax quadricarinatus encodes a lipoprotein with calcium binding ability and its expression is induced following the removal of the androgenic gland in a sexually plastic system. Gen Comp Endocrinol. 127:263-272.

Avarre J C, Michelis R, Tietz A, Lubzens E.2003. Relationship between vitellogenin and vitellin in a marine shrimp, Penaeus semisulcatus molecular characterization of vitellogenin complimentary DNAs Biol. Reprod.; 69: 355-364.

Byard E H, Aiken D E. 1984. The relationship between molting, reproduction, and a hemolymph female-specific protein in the lobster, Homarus americanus. Comp Biochem Physiol 77A:749-757.

Kulkarni Arvind and Balkhande Jayvardhan 2016. Prevention of urea toxicity in DNA and RNA content of a fresh water field crab, Barytelphusa guerini by using Sulphur containing amino acid Methionine as an additive Int. J. of Life Sciences, 2016, Vol. 4 (2): 263-266 ISSN: 2320-7817| eISSN: 2320-964X

Pooyan, R, 1998. Determination of the site of vitellogenin synthesis in the ridgeback shrimp, Sicyonia ingentis. Master's
I am thankful to the University Grants Commission (WRO), for providing financial assistance (Grant No. F: 47-152/07 WRO). I am also thankful to Principal Shri Anand College, Pathardi for providing necessary laboratories facilities to carry out present work.

Thesis, Department of Biology, California State University, Fresno

Ravikiran and Kulkarni 2015. Nucleic acid content in different tissues of the fish, $N$. notopterus in relation to sex International Letters of Natural Sciences vol. $7: 1-6$

Raviv Shaul, Shmuel Parnes, Carmen Segall, Claytus Davis, Amir Sagi, 2006. Complete sequence of Litopenaeus vannamei (Crustacea: Decapoda) vitellogenin cDNA and its expression in endocrinologically induced sub- adult females. General and Comparitive Endocrinology, 145: 39-50.

Rosa and M L Nunes 2004. Seasonal changes in nucleic acids, amino acids and protein content in juvenile Norway lobster (Nephrops norvegicus). Marine Biology 143(3): 565-572.

Sambrook, J, E F Fritsch, and T Maniatis, 1989. Molecular cloning. A laboratory manual. Cold Spring Harbor Laboratory Press, Cold Spring Harbor

Shirley Hiu Kwan Tiu, John Benzie, Siu-Ming Chan.2008. From hepatopancreas to ovary: Molecular characterization of a shrimp processing of vitellogenin. Biol. Reproduction: 18218613.

Tseng WS, Quackenbush LS, Chow BK, Tiu SH, He, JG, Chan SM, 2003 Organization of the shrimp vitellogenin gene: evidence of multiple genes and 
I J R B A T, Issue (VIII), Vol. II, May 2020: 85-91

tissue specific expression by the ovary and hepatopancreas. Gene; 303: 99-109.

Tsukimura, B, J S Bender, and C J Linder 2000. Developmental aspects of gonadal regulation in the ridgeback shrimp, Sicyonia ingentis. Comp. Biochem. Physiol, 127A: 215-224

Tsukimura B 2001. Crustacean vitellogenesis: its role in oocyte development. Am Zool 41: 465-476

Tsutsui N, Kawazoe I, Ohira T, Jasmani S, Yang WJ, Wilder MN, Aida K 2000 Molecular characterization of a cDNA encoding vitellogenin and its expression in the hepatopancreas and ovary during vitellogenesis in the kuruma prawn
Penaeus Japonicus. Zool. Sci.; 17: 651660

Tsutsui N Saido-Sakanaka , Yang WJ, Jayasankar V, Jasmani S, Okuno A, Ohira T, Okumura T, Aida K, Wilder MN 2004. Molecular characterization of a cDNA encoding vitellogenin in the coonstriped shrimp, Pandalus hypsinot

Weiqun Lu, Geoffrey Wainwright, Lisa A Olohan, Siman G Webster, Huw H Rees, Philip C Turner 2001. Characterization of c DNA encoding molt- inhibiting hormone of the crab, Cancer pagurus; expression of $\mathrm{MIH}$ in non-X organ tissues. Gene, 278: 149-159.

Table-1: Seasonal change in DNA content in ovary, testis and hepatopancreas of Barytelphusa guerini for the period January to December 2014

\begin{tabular}{|c|c|c|c|}
\hline \multirow{2}{*}{ Month } & Ovary DNA & Testes DNA & Hepatopancreas DNA \\
& Average $(\mu \mathrm{g} / \mathrm{gm}) \pm \mathrm{SD}$ & Average $(\mu \mathrm{g} / \mathrm{gm}) \pm \mathrm{SD}$ & Average $(\mu \mathrm{g} / \mathrm{gm}) \pm \mathrm{SD}$ \\
\hline January & $38.5 \pm 5.50$ & $328.9 \pm 5.52$ & $258.7 \pm 22.22$ \\
\hline February & $41.4 \pm 4.50$ & $358.8 \pm 4.48$ & $278.58 \pm 24.26$ \\
\hline March & $53.3 \pm 4.62$ & $379.8 \pm 5.56$ & $281.7 \pm 22.20$ \\
\hline April & $51.3 \pm 4.68$ & $368.66 \pm 4.86$ & $307.6 \pm 23.20$ \\
\hline May & $49.4 \pm 4.61$ & $397.6 \pm 4.62$ & $295.3 \pm 24.20$ \\
\hline June & $52.4 \pm 4.62$ & $404.8 \pm 4.26$ & $293.3 \pm 23.10$ \\
\hline July & $57.3 \pm 4.61$ & $414.7 \pm 4.62$ & $298.32 \pm 23.10$ \\
\hline August & $61.32 \pm 4.64$ & $412.7 \pm 4.44$ & $333.3 \pm 23.10$ \\
\hline September & $65.3 \pm 4.62$ & $406.7 \pm 4.61$ & $289.78 \pm 21.32$ \\
\hline October & $59.44 \pm 4.54$ & $388.65 \pm 4.34$ & $263.4 \pm 21.56$ \\
\hline November & $42.6 \pm 5.54$ & $354.3 \pm 5.56$ & 22.44 \\
\hline December & $40.4 \pm 5.22$ & $344.2 \pm 5.52$ & \\
\hline
\end{tabular}

Fig : 1 Frequency histogram showing mean DNA content in gonads and hepatopancreas of Barytelphusa guerini for the period January to December 2014 


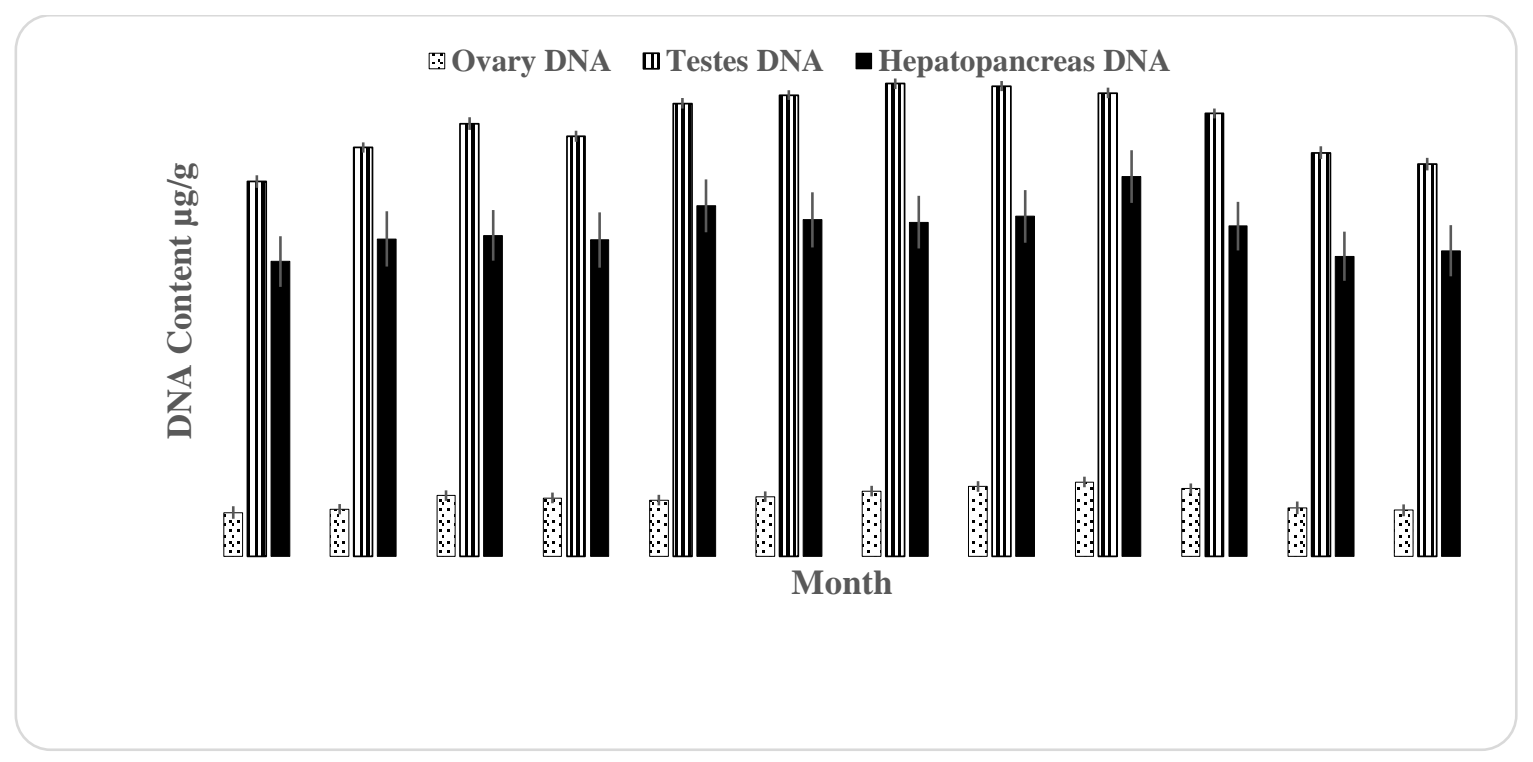

Table-2: Seasonal change in RNA content in ovary, testis and hepatopancreas of Barytelphusa guerini for the period January to December 2014

\begin{tabular}{|c|c|c|c|}
\hline Month & Ovary RNA & Testes RNA & Hepatopancreas RNA \\
& Average $(\mu \mathrm{g} / \mathrm{gm}) \pm \mathrm{SD}$ & Average( $\mu \mathrm{g} / \mathrm{gm}) \pm \mathrm{SD}$ & Average( $\mu \mathrm{g} / \mathrm{gm}) \pm \mathrm{SD}$ \\
\hline January & $81.5 \pm 12.50$ & $363.7 \pm 0.716$ & $297.8 \pm 2.82$ \\
\hline February & $84.6 \pm 18.45$ & $378.58 \pm 0.854$ & $312.5 \pm 2.78$ \\
\hline March & $94.4 \pm 11.20$ & $392.6 \pm 0.615$ & $333.3 \pm 2.81$ \\
\hline April & $96.64 \pm 12.55$ & $394.6 \pm 0.688$ & $339.3 \pm 3.12$ \\
\hline May & $97.5 \pm 11.50$ & $396.7 \pm 0.614$ & $358.4 \pm 2.82$ \\
\hline June & $108.8 \pm 9.08$ & $426.7 \pm 0.616$ & $362.28 \pm 2.24$ \\
\hline July & $107.6 \pm 8.24$ & $432.72 \pm 0.584$ & $363.7 \pm 2.81$ \\
\hline August & $93.4 \pm 9.84$ & $430.58 \pm 0.784$ & $348.8 \pm 2.62$ \\
\hline September & $91.24 \pm 8.86$ & $432.54 \pm 0.654$ & $362.8 \pm 2.66$ \\
\hline October & $89.6 \pm 11.08$ & $427.7 \pm 0.615$ & $302.4 \pm 2.84$ \\
\hline November & $87.3 \pm 10.80$ & $370.8 \pm 0.715$ & $308.4 \pm 2.34$ \\
\hline December & $82.64 \pm 11.26$ & $384.28 \pm 0.716$ & \\
\hline
\end{tabular}

Fig: 2 Frequency histogram showing mean RNA content in gonads and hepatopancreas of Barytelphusa guerini for the period January to December 2014 


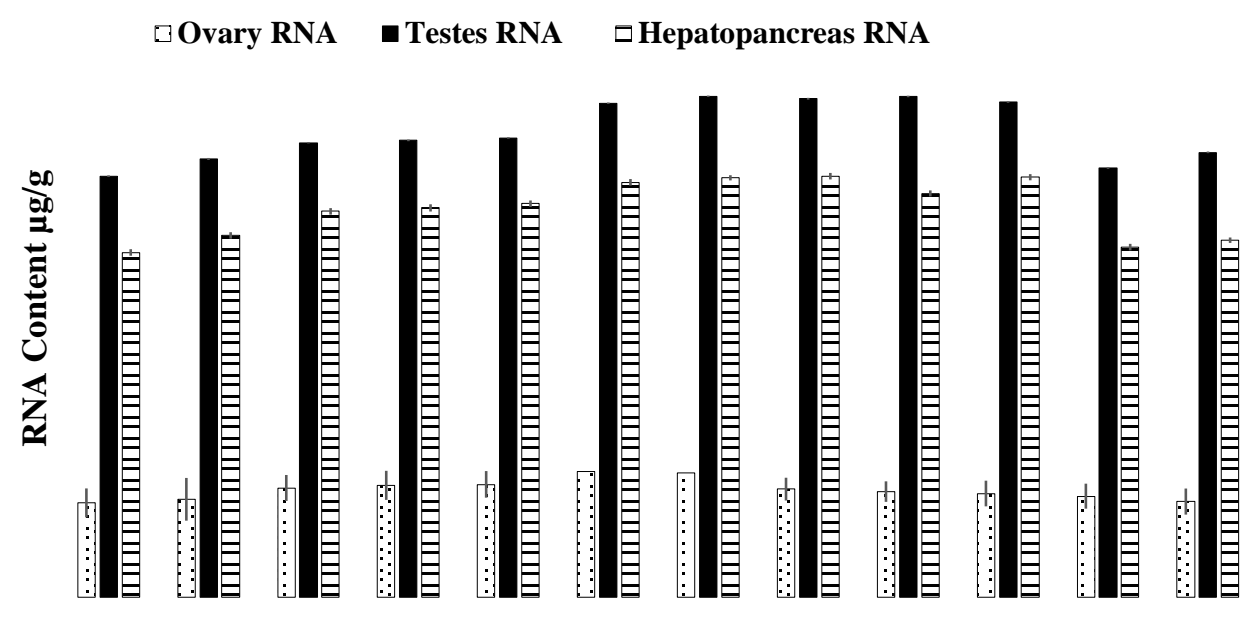

Month 